\title{
CYP2C19*3 Allele
}

National Cancer Institute

\section{Source}

National Cancer Institute. CYP2C19*3 Allele. NCI Thesaurus. Code C45606.

Human CYP2C19*3 allele is located within 10q24.1-q24.3 and is approximately $90 \mathrm{~kb}$ in length. This allele, a variant form of the CYP2C19 wild-type allele, encodes cytochrome P450 2C19*3 protein. The CYP2C19*3 allele exhibits a clinically-relevant SNP (c.636G>A) in exon 3 that results in a W212X coding change. This alteration in protein sequence abolishes the enzymatic activity of the cytochrome $\mathrm{P} 4502 \mathrm{C} 19 * 3$ protein. 